journey through space-time we have to pass through many passages which lead from one period in our lives to another period. For example, there are the passages from infancy to childhood, from childhood to adolescence, adolescence to adulthood, and finally the abrupt passage through the doorway of death, either to annihilation or to an entirely different form of life beyond the grave.

Gennep has noted two facts about these transition periods of man's life. The first is that each of these movements has its appropriate rules and rites and that the ceremonies which accompany them are very much the same in all civilizations and cultures. He also directs attention to the fact that these cultures accentuate the existence of two particularly sharp divisions in society, the first being the sexual division between the men and the women and the second the magico-religious division between the religious members of society and the profane members. He gives a description also of the secondary groupings of the various age-groups, the family units and the politico-administrative and territorial units.

Life entails for everybody many separations followed by subsequent re-unions, and one of the author's main purposes in writing this book was to investigate the precise significance of the rites which are, and which always have been, associated with these passages of separation and re-union. This led him to investigate the various initiation rites in the mystery religions of Egypt and Greece, religions which exerted a great influence on the ceremonies and rituals of the Christian Church in its early formative years. Indeed, it may be said that the rituals of the Catholic Mass are representations of a number of transitions and incorporations, the only difference between these and the initiation rituals of the old mystery religions being that the initiation ceremonies of the Mass are never final but are always being renewed.

Arnold van Gennep's book covers a great deal of ground, and it should be of interest not only to anthropologists but also to students of religions. Its appearance in an English edition is to be welcomed.

KenNeth Walker

\section{AFRICAN CULTURES}

\section{Continuity and Change in African Cultures}

Edited by William R. Bascon and Melville J. Herskovits. Pp. vii +309 . (Chicago : University of Chicago Press; London : Cambridge University Press, 1959.) $52 s .6 d$. net.

7 HIS is one of the better collections of essays on Africa that have appeared in recent years. The introductory essay by the editors is an excellent summary of the problem, directing attention to some of the basic approaches to the subject which are too often lost sight of in the hurry of modern research. Four essays deal with "Africa as a Linguistic Area" (Greenberg), "African Art" (Cordwell), "African Music" (Merriam), and "The Factor of Polygyny in African Demography" (Dorjahn). The remaining nine are regional or tribal studies, two of them dealing with eastern Africa, one with the north-western Belgian Congo, and the rest with west Africa. Though there are three maps, illustrating language groups, culture groups, and music areas, it would have been helpful if a map had been included showing where the peoples studied are to be found.

Although the subject of the book is specifically "continuity and change in cultures", there is none the less a good deal of information about various aspects of the peoples represented; and unlike so much modern work on Africa, the book is mercifully free, to a great extent, from the jargon and involved writing that seems to be considered a necessary element in social anthropology to-day.

Of particular interest to historians should be the essay on "Ethno-History in the Study of CultureChange in South-east Africa", which is an interesting, informative, and well-documented study, though it needs a map of its own; in fact each of the regional essays would have benefited by a map.

In his account of the Pakot (better written Pokoot), Prof. Schneider might have added the story of how Chaundy managed to persuade the people to use their stocks of cow-dung for fertilizer instead of keeping them merely as visible indicators of wealth, but gave up doing it when he had gone.

Although the book is intended as a study of various aspects of acculturation, it forms quite a useful introduction to the peoples with which it deals. The essay on "African Art" is a comprehensive survey of art throughout the continent, concentrating mainly, as is to be expected, on West Africa; but there are short sections on Eastern and Southern Africa and the Congo, and on modern African art. The author notes that "there are few African cultures where the concept of 'art for art's sake' seems to have existed" ; I wonder if this is really true. The essay which follows this, on African music, is equally comprehensive.

At a time when so many anthropological studies of Africa tend to be of the 'social anthropological' kind, it is good to come across a book like this which deals with facts, and allows the facts to retain their importance. Though some of the essays in the book are within the field of social anthropology, the importance of the facts on which they are based is not minimized. This book is altogether to be recommended to those who wish to know more about certain aspects of African cultures before the countries in which they are found become independent and possibly undergo change in a different direction.

G. W. B. HUNTINGFORD

\section{SELF-REGULATION FOR CHILDREN}

The Free Family

A Creative Experiment in Self-Regulation for Children. By Paul and Jean Ritter. Pp. $269+4$ plates. (London: Victor Gollancz, Ltd., 1959.) $18 s$. net.

THE authors of this book were inspired by the teachings of Wilhelm Reich and the example to A. S. Neill to bring up their five daughters in accordance with the principle of 'self-regulation'. According to this principle, children should be left to work out for themselves how they shall behave; when and what they shall eat, when they shall sleep, when eliminate, and so on. Adult interference is kept to the minimum necessary for the children's safety, and to prevent them from becoming too much of a social nuisance. Their lives begin with the birth procedures advocated by Dr. Dick Read. 